\title{
Seroepidemiology and associated risk factors of Toxoplasma gondii in sheep and goats in Southwestern Ethiopia
}

\author{
Dechassa Tegegne* ${ }^{*}$, Amin kelifa, Mukarim Abdurahaman and Moti Yohannes
}

\begin{abstract}
Background: T.gondii is a global zoonotic disease and is considered as the most neglected tropical disease in sub-Saharan countries. The exact seroepidemiological distribution and risk factors for the infection of food animals and humans in Ethiopia was less studied although, such studies are important. The objective of the current study was to determine the seroprevalence and potential risk factors of $T$. gondii infection in sheep and goats in Southwestern Ethiopia.
\end{abstract}

Methods: Cross sectional study was conducted from November 2014 to March 2015 in South west Ethiopia in four selected districts of Jimma zone $(n=368)$. Slide agglutination test (Toxo-latex) was used to detect anti-T.gondii antibodies. Logistic regression was used to determine potential risk factors.

Results: An overall seroprevalence of 57.60\% (212/368; 95\% Cl: 52.55-62.6) was detected. 58.18\% (148/252; 95\% Cl: 52.75-64.88) and 55.18\% (64/116; 95\% Cl: 46.13-64.23) sero prevalence was found in sheep and goats respectively. Multivariable logistic regression analysis showed that the risk of $T$. gondii infection was significantly higher in adult sheep and goats [(sheep: Odds Ratio $(\mathrm{OR})=2.5$, confidence interval $(\mathrm{Cl}): 1.19-5.23 ; p=0.015)$, (goats: $\mathrm{OR}=3.9$, confidence interval (Cl):1.64-9.41: $p=0.002)]$ than in young sheep and goats, in female [(sheep: OR=1.93, Cl: 1.11-3.36, $p=0.018$, (goats: $\mathrm{OR}=2.9, \mathrm{Cl}: 121-6.93, p=0.002)]$ than in males sheep and goats, in Highland [(sheep: $\mathrm{OR}=4.57$, $\mathrm{Cl}: 1.75-12.66, P=0.000$, (goats: $\mathrm{OR}=4.4, \mathrm{Cl}: 1.75-13.66, p=0.004$ )] than sheep and goats from lowland.

Conclusion: This study indicates that seroprevalence of latent toxoplasmosis in small ruminants is high, therefore, it is decidedly indispensable to minimize risk factors exposing to the infection like consumption of raw meat as source of infection for humans.

Keywords: Goat, Sheep, Toxo-latex, T. gondii, Seroprevalence, Southwestern Ethiopia

\section{Background}

Toxoplasmosis is zoonotic disease caused by an obligate intracellular parasite known as T. gondii [1]. It is the most prevalent parasitic infections in human and veterinary medicine and has negative impacts on public health and animal production. T. gondii is believed to be the most triumphant parasitic pathogen in large scale [1]. Despite having adverse health effects analogous to those of salmonellosis and campylobacteriosis, toxoplasmosis is still a neglected and underreported parasitic

\footnotetext{
* Correspondence: dachassat@yahoo.com

Department of Veterinary Microbiology and Public Health, College of Agriculture and Veterinary Medicine, School of Veterinary medicine, Jimma University, PO. Box 307, Jimma, Ethiopia
}

infection. Human vaccines are not available and the results of the usage of the current anti-parasitic therapies are quite disappointing [2].

Toxoplasmosis is found globally; almost one third of the human population $[1,3]$. The occurrence of toxoplasmosis has been significantly increasing as a result of the opportunistic infection of immune compromised patients, for instance, acquired immune deficiency syndrome (AIDS). In these people deaths usually result from rupture of cysts that lead to continued multiplication of tachyzoites [4]. Hence, encephalitis was presented as the main clinical manifestation of toxoplasmosis in AIDS patients as a result of reactivation of latent infection [5]. Majority of ocular cases at the present are associated with acquired 
toxoplasmosis, thus preventive strategies should be focused not only on pregnant women but also in the general population [2].

From wide range of farm animals, sheep and goats are more commonly infected with T.gondii than cattle and chicken. This parasite causes abortion and neonatal death in major monetary losses to sheep, goat and pig farming $[3,5]$. This is more serious especially when primary infection occurs during pregnancy [6].

For evaluating the comparative significance of wide causes of toxoplasmosis in human's epidemiological survey still remains the main important approach. There have been a wide range of serological surveys conducted in different countries to determine the prevalence of toxoplasmosis in farm animals and humans; from North and South America [7-13], Europe [14-16], Africa [17-23] Asia [24, 25]. According to Australian Centre for International Agricultural Research (ACIAR) [26] T.gondii is extensively spread among farm animals and human with variable seroprevalence rates of $11-61 \%$ in goats, less than $10 \%$ in cows, $35-73 \%$ in cats, $75 \%$ in dogs, $11-36 \%$ in pigs, and $35-73 \%$ in humans.

In Africa different reports indicate widespread occurrence of toxoplasmosis. Thirty percent infection rate of toxoplasmosis was reported in goats in Botswana [20]. Limited studies have been carried out to investigate the magnitude of toxoplasmosis in animals and humans in Ethiopia so far. A preliminary serological study made in sheep and goat population around Nazareth showed an overall seroprevalence of $54.7 \%$ in sheep and $26.7 \%$ in goats using Enzyme linked Immunosorbent Assay (ELISA) and Modified Agglutination Test (MDAT) [21]. In another seroprevalence study of human toxoplasmosis of workers at Addis Ababa abattoir [22], reported a prevalence of 96.8\% using an indirect haemagglutination assay [16], 80.7\% in HIV patients in Agaro Health Centre in Jimma Zone [27] on top of this 6.6, 22.9 and $11.6 \%$ prevalence was reported in cattle, sheep and goats in central Ethiopia respectively [17].

In general, there is a scarcity of data on sero- epidemiology of toxoplasmosis in animals and humans in Ethiopia though numerous literatures associate human toxoplasmosis with utilization of raw/undercooked meat products of animal origin. The exact seroepidemiological distribution and risk factors for the infection of food animals in Jimma are unknown but, such studies are indispensable because consumption of raw meat is a popular tradition in Jimma. Thus, human toxoplasmosis in Jimma might have strong linkage with seroprevalence of the infection in food animals on top of this little is known about seroprevalence of T.gondii infection in sheep and goat Jimma zone. Therefore, the present study was intended with objective of estimating the seroprevalence and risk factors of T.gondii infection in small ruminants in Jimma zone.

\section{Methods}

\section{Study areas}

The study was carried out in four districts of Jimma zone namely Seka Chokorsa $20 \mathrm{~km}$ in Southeast, Mena $22 \mathrm{~km}$ in North east, Kersa $18 \mathrm{~km}$ in Northwest and Goma $50 \mathrm{~km}$ west of the Jimma. Jimma is a capital city of of Jimma zone which is located in Oromia regional state found $352 \mathrm{~km}$ away from the capital city (Addis Ababa) in the southwest Ethiopia. It is located at latitude of $7^{\circ} 13^{\prime}-8^{\circ} 56^{\prime} \mathrm{N}$ and longitude of $35^{\circ} 52^{\prime}-37^{\circ} 37^{\prime} \mathrm{E}$, and at an altitude ranging from $880 \mathrm{~m}$ to $3360 \mathrm{~m}$ above sea level (masl). The study areas were purposively selected to represent three agro-ecological zones such as highland ( $\geq 2300$, masl), midland (1500-2300 masl) and lowlands $(\leq 1500$ masl). The area receives about $1530 \mathrm{~mm}$ rainfall that comes from the long and short rainy seasons. The mean temperature yearly ranges from 25 to $30{ }^{\circ} \mathrm{C}$ and 7 to $12{ }^{\circ} \mathrm{C}$ [28] (Additional file 1: Figure S1).

As it was reported by Central Statistical Agency census [29], the total population of Jimma zone is 2,642,114, from these Jimma town populations accounts 177,900 (Ethiopian statistical agency 2015 projected from 2007 census), 49.7 and $49.3 \%$ females and males respectively). From the total population in the zone, 2,204,225 (88.66\%) are rural community engaged in agricultural activities for their livelihood. Jimma zone is potential source of livestock which contribute to the country growth and domestic production; about 466,154 of sheep, 194,677 of goats, $1,718,284$ of cattle, 40,555 of donkeys, 30,541 of mules and 74,774 of horses [30].

\section{Study animals}

The study subjects were sheep and goats. Small ruminant production in the study areas was mainly characterized by traditional and extensive type of management system. Mainly male's sheep and goats are known to be kept for mutton production in most parts of the country while females are for breeding. The study dealt with animals kept by peasants in four districts of Jimma zone.

\section{Study design and sample size}

Cross-sectional study design was used. Different age and sex groups of sheep and goats were included for this study. The study was conducted from November 2014 to March 2015. Serological investigation was used to detect anti-T.gondii antibodies from blood serum collected from sheep and goats in the districts under study. Since there was no previous expected prevalence in the area, sample size was calculated as it is stated by Thrusfield [31] using an expected prevalence of $50.0 \%$ a desired precision of $5 \%$ and with $95 \%$ level of confidence. Hence, the sample size was 384 . Basically due to the fact that goat's population at study area was very limited in number, therefore, only 116 goats and 252 of sheep sera were 
subjected to analyses, totally 368 samples were analyzed. Simple random sampling technique was carried out to collect sera from small ruminants.

\section{Blood collection}

Sheep and goats was aseptically bled (approximately $5 \mathrm{ml}$ ) from the jugular vein by using $10 \mathrm{ml}$ vacutainer tubes which contained no anti-coagulants or preservatives and vein puncture needle and needle holder was used and properly labelled with water proof marker with the necessary information. Blood sample was transported to Jimma University, microbiology and veterinary public health laboratory and was kept overnight at room temperature and then centrifuged at $3000 \mathrm{rpm}$ for $10 \mathrm{~min}$ to get serum. The serum was collected in $1.5 \mathrm{ml}$ Eppendorf tubes and kept at $-20{ }^{\circ} \mathrm{C}$ until serologically tested for the presence of anti $T$. gondii antibodies.

\section{Serological examination}

T. gondii antibodies were detected by the Toxo Latex slide Agglutination test following the procedure described by manufacturer SPINREACTGirona/Spain. Briefly, $50 \mu \mathrm{L}$ sera samples was placed on toxo-latex agglutination slide and one drop of each positive and negative control into separate circles on the slide test and mixed thoroughly. $25 \mu \mathrm{L}$ of toxo-latex reagent was added to $50 \mu \mathrm{L}$ sera samples into separates circles and mixed thoroughly with stirrer then the mixture was spread over entire circle. The slide was placed on mechanical rotator at $96 \mathrm{rpm}$ for $4 \mathrm{~min}$. The presence or absence of visible precipitation was macroscopically examined immediately after removing the slide from the rotator. The formation of precipitation was recorded as positive and it indicates an antibody concentration equal or greater than $4 \mathrm{IU} / \mathrm{ml}$.

\section{Data analysis}

Data were recorded and coded using Microsoft Excel spreadsheet and analysed using SPSS version 20. Seroprevalence was calculated by dividing the number of animals possessing anti-T.gondii antibodies against the total number of animals tested. Relationship of risk factors with dependent variable was primarily assessed using cross tabulation. Univariable logistic regression analysis was performed and strength of association between risk factors and T. gondii infection were evaluated using odds ratios (OR). The 95\% confidence interval (CI) and a significance level of $\alpha=0.05$ were used.

\section{Result}

Overall seroprevalence

Out of 368 animals examined 212 (57.60\%, 95\% CI: 52.55-62.65) were seropositive for T.gondii antibody; 58.8\% (148/252; 95\% CI: 52.75-64.88) and 55.18\% (64/116; 95\% CI: 46.13-64.23) seroprevalence was found in sheep and goats respectively. Both serum samples from sheep and goats showed positive reactions of similar proportions (Table 1 ). Their variation is statistically insignificant $(P>0.05)$.

\section{Risk factors}

Results of logistic regression analysis indicates that the potential risk factors related to sex, age and altitude revealed that the likelihood of $T$. gondii infection was higher in adult sheep $(\mathrm{OR}=2.5)$, female sheep $(\mathrm{OR}=1.95)$ and highland $(\mathrm{OR}=4.57)$ when compared with male, young

Table 1 Seroprevalence of T. gondii antibody and logistic regression analysis of risk factors for sheep

\begin{tabular}{|c|c|c|c|c|c|c|}
\hline \multirow{2}{*}{$\begin{array}{l}\text { Risk factors } \\
\text { Species }^{a}\end{array}$} & \multirow[t]{2}{*}{ Total } & \multirow[t]{2}{*}{ No of positive } & \multicolumn{2}{|l|}{ Univariable } & \multicolumn{2}{|l|}{ Multivariable } \\
\hline & & & COR $(95 \% \mathrm{Cl})$ & $P$-Value & AOR $(95 \% \mathrm{Cl})$ & $P$-Value \\
\hline Sheep & 252 & 148 (58.73\%) & - & & - & \\
\hline Goat & 116 & 64 (55.18\%) & - & & - & \\
\hline Total & 368 & $212(57.60 \%)$ & & & & \\
\hline \multicolumn{7}{|l|}{ Age } \\
\hline Young (<1 year) & 40 & 15 (37.5\%) & 1 & & 1 & \\
\hline Adult (>1 year) & 212 & $133(62.7 \%)$ & $2.8(1.39,5.63)$ & 0.004 & $2.5(1.19,5.23)$ & 0.015 \\
\hline \multicolumn{7}{|l|}{ Sex } \\
\hline Male & 99 & 46 (46.5\%) & 1 & & & \\
\hline Female & 153 & $102(66.7 \%)$ & $2.3(1.37,3.87)$ & 0.002 & $1.93(1.11,3.36)$ & 0.018 \\
\hline \multicolumn{7}{|l|}{ Altitude } \\
\hline Highland & 113 & 79 (69.9.9\%) & $5.07(2.23,1163)$ & 0.000 & $4.57(1.75,12.66)$ & 0.000 \\
\hline Midland & 104 & $58(55.8 \%)$ & $2.75(1.22,6.19)$ & 0.015 & $2.8(1.23,6.54)$ & 0.014 \\
\hline Lowland & 35 & 11 (31.4\%) & 1 & & & - \\
\hline
\end{tabular}

COR crude odd ratio, $A O R$ adjusted odd ratio, $C I$ Confidence Interval

${ }^{\text {a }}$ Species, $P=0.213$ 
and lowland sheep respectively (Table 1 ). On top of this, the likelihood of $T$. gondii infection was higher in adult goats $(\mathrm{OR}=2.5)$, female goats $(\mathrm{OR}=1.95)$ and highland $(\mathrm{OR}=4.4)$ when compared with male, young and lowland goats, respectively (Table 2).

\section{Discussion}

Out of 368 animals examined the seroprevalence of anti-T.gondii antibody was found $212(57.60 \%)$. This is comparable to the previous report from Ethiopia [32]. Different studies revealed that the prevalence from 0 to $100 \%$ was recorded in different areas of the world [33]. This difference in prevalence is depending up on cat density, climate condition, age of the animals, species, sex, altitude and management of animal production [3, 5, 34].

Lower prevalence values of 3.8, 4.3, 11.2, 12.1 and $16.9 \%$ were recorded by Sharma [35] in India, Samra [36] in South Africa, Ramzan [37] in Pakistan, Dubey and Foreyt [38] in the North America and Márcia de Figueiredo [12] in Brazil respectively. The current study estimated seroprevalence of T.gondii antibody in sheep was 58.73\% and this is in agreement with the finding of 56.00\% [32] in Central Ethiopia and higher seroprevalence in sheep has been reported when compared to the present finding $[3,12,39,40]$.

The seroprevalence of T.gondii antibody in goats was $55.18 \%$ is closely related to the finding of $59.4 \%$ from Egypt [41], but it is higher than the finding of 19.70 and 37.20\% reported by Zewdu et al. [39, 42] and Yibeltal, [43] in Central Ethiopia and in South Wollo respectively. It is also higher than the $39,31.7,28.9,27.9$ and $25.4 \%$, reported from Thailand [44], Pakistan [37] and Brazil $[12,13,23]$ respectively. In contrast, the prevalence of the present study is lower than the $67.9 \%$ reported from Zimbabwe [45]. The variations in the overall prevalence observed in the current study and the above studies could be due to differences in the access of small ruminants to contaminated feed and water, the climatic variation and the diagnostic techniques used $[34,46]$.

The present study indicated that sheep from the highland $(\mathrm{OR}=4.57, \mathrm{CI}: 1.75-12.66)$ and midland $(\mathrm{OR}=2.8$, CI: 1.23-6.54) areas of Southwest Ethiopia have significantly $(P=0.000)$ high risk of infection of T.gondii than those of from the lowland. Similarly, goats from the highland $(\mathrm{OR}=4.4, \mathrm{CI}: 1.75-15.5)$ and midland $(\mathrm{OR}=3.9, \mathrm{CI}$ : 1.64-9.41) areas of Southwest Ethiopia have significantly higher risk of $T$. gondii infection than those from the lowland $(P=0.004)$. This study was in agreement with the finding of $46.91 \%$ in highland and $46.24 \%$ in midland but lower prevalence in lowland $13.36 \%$ [39, 42] in Central Ethiopia. This variation among risk factors can be described by the variation in temperature and moisture in these areas. It is well known that the epidemiology of toxoplasmosis is influenced by the environment [3, 34]. Humidity increases, the chance of oocyst survival in the environment, thereby contributing to the higher seroprevalence. A dry climate has an impact on the survival and epidemiological distribution of the parasite $[1,47]$.

Correspondingly, seroprevalence of T.gondii antibody was high in adults $(62.7 .4 \%$ sheep and $65.8 \%$ goats) than in young animals (37.5.09\% sheep and 35\% goats). Statistically significant variation was observed among them. This finding is relatively similar to $[48,49]$ that reported prevalence $(10.00 \%)$ in young and $(26.76 \%)$ in adult. Multivariable logistic regression analysis showed that the likelihood of acquiring infection was higher in adult [(sheep: $\mathrm{OR}=2.5$, CI: $1.19-5.23 ; P=0.015$ ), (goats: $\mathrm{OR}=3.9, \mathrm{CI}: 1.64-9.41: p=0.002)]$ than in young sheep and goats. Seroprevalence of T.gondii antibody increases with age in both species. This could be attributed to the reality that increment of the disease prevalence in older animals is due to exposure of animals to the risk factors for longer period of time than the younger ones $[1,12,13,39,42]$. With regard to sex risk factor, the

Table 2 Seroprevalence of T.gondii and logistic regression analysis of risk factors for goats

\begin{tabular}{|c|c|c|c|c|c|c|}
\hline \multirow[t]{2}{*}{ Risk factors } & \multirow[t]{2}{*}{ Total } & \multirow[t]{2}{*}{ No of positive } & \multicolumn{2}{|l|}{ Univariable } & \multicolumn{2}{|l|}{ Multivariable } \\
\hline & & & COR $(95 \% \mathrm{Cl})$ & $P$-value & AOR $(95 \% \mathrm{Cl})$ & $P$-Value \\
\hline \multicolumn{7}{|l|}{ Age } \\
\hline Young ( $<1$ year $)$ & 40 & $14(35 \%)$ & & & & \\
\hline Adult (>1 year) & 76 & $50(65.8 \%)$ & $3.57(1.59,7.98)$ & 0.002 & $3.9(1.64,9.41)$ & 0.002 \\
\hline \multicolumn{7}{|l|}{ Sex } \\
\hline Male & 42 & $18(42.9 \%)$ & 1 & & & \\
\hline Female & 74 & 46 (62.2\%) & $2.19(1.01,4.73)$ & 0.035 & $2.9(1.21,6.93)$ & 0.002 \\
\hline \multicolumn{7}{|l|}{ Altitude } \\
\hline Highland & 59 & 38 (67.9\% & $4.52(57,13.5)$ & 0.005 & $4.4(1.75,15.5)$ & 0.004 \\
\hline Midland & 38 & 19 (50\%) & $2.14(0.714,6.43)$ & 0.174 & $3.9(1.64,9.41)$ & 0.10 \\
\hline Lowland & 22 & 7 (31.8\%) & 1 & & & - \\
\hline
\end{tabular}

COR crude odd ratio, $A O R$ adjusted odd ratio, $C I$ Confidence Interval 
study showed that the seroprevalence of anti-T.gondii antibody is higher in females (60.9\%) than in males (54.64\%) in both species. The result was similar to the finding of Zewdu et al. [39, 42] in female (34.39\%) and males (19.43\%).

Multivariable logistic regression analysis revealed that the likelihood of acquiring infection was higher in females [(sheep: OR $=1.93, \quad \mathrm{CI}: 1.11-3.36, p=0.018)$, (goats: $\mathrm{OR}=2.9$, CI: $121-6.93, p=0.002$ )] than in males sheep and goats. A small number of male sheep and goats are kept for breeding whilst others are culled and sold. In addition, the stress of lactation and pregnancy due to hormonal difference lead to immune-suppression that may expose the female sheep and goats to toxoplasmosis [50].

\section{Conclusions}

This study indicated that seroprevalence of latent toxoplasmosis in small ruminants is high. Therefore, it is particularly requisite providing health education about its public health importance and risk factors that expose to humans the infection such as consumption of raw meat of small ruminants.

\section{Additional files}

Additional file 1: Figure S1. Map of study districts. (JPG 324 kb)

Additional file 2: Raw data of sheep and goats. (XLSX 17 kb)

\section{Acknowledgement}

The author highly acknowledges Jimma University College of Agriculture and Veterinary Medicine, laboratory of Microbiology for the facility provision as well as those laboratory attendants who technically assisted this study. The authors again highly acknowledge the institute which financially supports this study.

\section{Funding}

This work was supported financially by Jimma University College of Agriculture and Veterinary medicine (JUCAVM).

\section{Availability of data and materials}

Data are attached separately along with this manuscript as Additional files 1 and 2 .

\section{Authors' contributions}

DT conceived and designed the study protocol. DT, AK, MA and MY carried out sample collection and serological examination. DT, AK and MY interpreted the results of data analysis and drafted the manuscript. DT and MY prepared study area map using GIS and performed statistical analysis. DT, MA, and MY compiled the results, improved and corrected the manuscript. All authors read, commented and approved the final manuscript. All authors read and approved the final manuscript.

\section{Competing interest}

The authors declare that they have no competing interests.

\section{Consent for publication}

Not applicable.

\section{Ethics approval and consent to participate}

Before the commencement this research was reviewed and approved by Jimma University Research and Ethics Review Board (REB). Animals involved in this research were handled with good animal handling practice and consent was obtained from the owners of the animals to conduct the study.

Received: 16 March 2016 Accepted: 30 November 2016

Published online: 09 December 2016

\section{References}

1. Dubey JP. Toxoplasmosis of animals and humans. 2nd ed. Beltsville: CRC Press; 2010. p. 1-338.

2. Kijlstra A, Jongert E. Toxoplasma-safe meat: close to reality? Trends Parasitol. 2008;25:18-22.

3. Tenter AM, Heckerotha AR, Weiss LM. Toxoplasma gondii: from animals to humans. Int J Parasitol. 2000;30:1217-58.

4. Roberts LS, Janovy J, Schimidt GD. Foundation of Parasitology. 7 thth ed. USA: McGraw-Hill Companies, Inc; 2000. p. 135-8.

5. Jithendran KP. Seroprevalence of Toxoplasma antibodies in domestic animals- an indicator of Toxoplasma gondii in the environment and human. ENVIS Bulletin Himalayan Ecol. 2004;12:22-8.

6. Radostits OM, Gay CC, Hinchcliff KW, Constable PD. Veterinary medicine: a textbook of the diseases of cattle, horses, sheep, pigs and goats. 10 thth ed. London: Sounders; 2006. p. 1518-22.

7. Dubey JP, Hill DE, Jones JL, Hightower AW, Kirkland E, Roberts JM, Marcet PL, Lehmann T, Vianna MCB, Miska K, Sreekumar C, Kwok OCH, Shen SK, Gamble HR. Prevalence of viable Toxoplasma gondii in beef, chicken, and pork from retail meat stores in the United States: Risk assessment to consumers. J Parasitol. 2005:91:1082-93.

8. Ragozo AMA, Yai LEO, Oliveira LN, Dias RA, Dubey JP, Gennari SM. Seroprevalence and isolation of Toxoplasma gondii from sheep from Sao Paulo State, Brazil. J Parasitol. 2008;96:1259-63.

9. Carneiro AC, Carneiro M, Gouveia AM, Guimaraes AS, Marques AP, Vilas-Boas LS, Vitor RW. Seroprevalence and risk factors of caprine toxoplasmosis in Minas Gerais, Brazil. Vet Parasitol. 2009;160:225-9.

10. Alvarado-Esquivel C, Torres-Castorena A, Liesenfeld O, Garcia-Lopez CR, Estrada-Martinez S, Sifuentes-Alvarez A, Marsal-Hernandez JF, Esquivel-Cruz R, Sandoval-Herrera F, Castaneda JA, Dubey JP. Sero-epidemiology of Toxoplasma gondii infection in pregnant women in rural Durango, Mexico. J Parasitol. 2009:95:271-4.

11. Lopes WDZ, Dos Santos TR, Da Silva RDS, Rossanese WM, De Souza FA, Rodrigues JDF, De Mendonca RP, Soares VE, Da Costa AJ. Seroprevalence and risk factors for Toxoplasma gondii in sheep raised in the Jaboticabal microregion, Sao Paulo State, Brazil. Res Vet Sci. 2010;88:104-6.

12. Pereira MF, Peixoto RM, Langoni H, Greca H, Azevedo SS, Porto WJN, Medeiros ES, Mota RA. Risk factors for Toxoplasma gondii infection in sheep and goats in Pernambuco, Brazil. Pesq Vet Bras. 2012;32(2):140-6.

13. Anderlini GA, Mota RA, Faria EB, Cavalcanti EF, Valença RM, Pinheiro Júnior $J W$, de Albuquerque PP, de Souza Neto O. Occurrence and risk factors associated with infection by Toxoplasma gondii in goats in the State of Alagoas, Brazil. Rev Soc Bras Med Trop. 2011;44(2):157-62.

14. Acici M, Babur C, Killie S, Hokelek M. Prevalence of antibodies to Toxoplasma gondii infection in humans and domestic animals in Samsun province, Turkey. Trop Anim Health Prod. 2008;40:311-5.

15. Pereira Bueno J, Quintanilla Gozalo A, Perez Perez V, Alvarez Gracia G, Collantes Fernandez E, Ortega Mora LM. Evaluation of ovine abortion associated with Toxoplasma gondii in Spain by different diagnostic techniques. Vet Parasitol. 2004;121:33-43.

16. Gilot-Fromont E, Aubert D, Belkilani S, Hermitte P, Gibout O, Geers R, Villena I. Landscape, herd management and within-herd seroprevalence of Toxoplasma gondii in beef cattle herds from Champagne-Ardenne, France. Vet Parasitol. 2009;161:36-40.

17. Bekele T, Kasali OB. Toxoplasmosis in sheep, goats and cattle in Central Ethiopia. Vet Res Commun. 1989:3:371-5.

18. Guebre-xabier M, Nurilign A, Gebre-Hiwot A, Hailu A, Sissay Y, Getachew E, Frommel D. Sero-epidemiological survey of Toxoplasma gondii infection in Ethiopia. Ethiop Med J. 1993;31:201-8.

19. Achu-Kwi MD, Ekue NF. Prevalence of Toxoplasma gondii antibodies in Djallonke sheep flocks in the Vina division, Cameroon. Bull Anim Health Prod Afr. 1994:42:89-92.

20. Sharma SP, Baipoledi EK, Nyange JF, Tlagae L. Isolation of Toxoplasma gondii from goats with a history of reproductive disorders and the prevalence of Toxoplasma and chlamydial antibodies. Onderstepoort J Vet Res. 2003;90:65-8. 
21. Negash T, Tilahun G, Medhin G. Seroprevalence of Toxoplasma gondii in Nazaret Town, Ethiopia. East Afr J Public Health. 2008;5:211-4.

22. Yimer E, Abebe P, Kassahun J, Woldemichael T, Bekele A, Zewdie B, Beyene M. Seroprevalence of human toxoplasmosis in Addis Ababa, Ethiopia. Ethiopian Vet J. 2005;9:123-8.

23. Bisson AS, Maley CM, Rubaire-Akiiki J, Watling M. The seroprevalence of antibodies to Toxoplasma gondii in domestic goats in Uganda. Acta Trop. 2000;76:33-8.

24. Yang H, Jin KN, Park YK, Hong SC, Bae JM, Lee SH, Choi HS, Hwang HS, Chung JB, Lee NS, Nam HW. Seroprevalence of toxoplasmosis in the residents of Cheju island, Korea. Korean J Parasitol. 2000;38:91-3.

25. Huang CQ, Lin YY, Dai AL, Li XH, Yang XY, Yuan ZG, Zhu XQ. Seroprevalence of Toxoplasma gondii infection in breeding sows in Western Fujian Province, China. Trop Anim Health Prod. 2010;42:115-8.

26. ACIAR (Australian Centre for International Agricultural Research). Assessment of zoonotic diseases in Indonesia. Canberra: ACIAR; 2007. p. 34-5.

27. Tegegne D, Abdurahaman M, Mosissa T, Yohannes M. Anti-Toxoplasma antibodies prevalence and associated risk factors among HIV patients. Asian Pac J Trop Med. 2016;9(5):460-4.

28. Tesema E. Zonal diagnosis and intervention plan report for Jimma zone. Ethiopia: LIVES. 2013. p. 13-20.

29. Central Statistical Authority (CSA). Summary and statistical report of the 2007 population and housing census results. Addis Ababa: EFDRE, Population census commission; 2008. p. 25-7.

30. Central Statistical Authority (CSA). Federal Democratic Republic of Ethiopia Central Statistical Agency Agricultural Sample Survey 2007/08. Volume II, report on livestock and livestock characteristics. Addis Ababa. Stat Bull. 2008:2:23-9.

31. Thrusfield M. Veterinary epidemiology. 3rd ed. London: Blackwell Science Ltd; 2005. p. 227-47.

32. Negash T, Tilahun G, Patton S, Prevot F, Dorchies PH. Serological survey of toxoplasmosis in sheep and goats in Nazareth, Ethiopia. Rev Med Vet. 2004:55:486-7.

33. Olivier A, Herbert B, Sava BC, Pierre D, John C, Aline DK. Surveillance and monitoring of Toxoplasma in humans, food and animals: a scientific opinion of the panel on biological hazards. European Food Safety Assoc J. 2007;583:1-64.

34. Dubey JP. Toxoplasmosis - a waterborne Zoonosis. Vet Parasitol. 2004;26:57-72.

35. Sharma S, Sandhu KS, Bal MS, Kumar H, Verma S, Dubey JP. Serological Survey of Antibodies to Toxoplasma gondii in Sheep, Cattle, and Buffaloes in Punjab, India. J Parasitol. 2008;94:1174-5.

36. Samra NA, McCrindle CM, Penzhorn BL, Cenci-Goga B. Seroprevalence of toxoplasmosis in sheep in South Africa. J South African Vet Assoc. 2007;78:116-20.

37. Ramzan M, Akhtar M, Muhammad F, Hussain Fl, Hiszczynska-Sawicka E, Haq AU, Mahmood MS, Hafeez MA. Seroprevalence of Toxoplasma gondii in sheep and goats in Rahim Yar Khan (Punjab), Pakistan. Trop Anim Health Prod. 2009;41:1225-9.

38. Dubey JP, Foreyt WJ. Seroprevalence of Toxoplasma gondii in Rocky Mountain big horn sheep (Ovis canadiansis). J Parasitol. 2000;86:622-3.

39. Gebremedhin EZ, Agonafir A, Tessema TS, Tilahun G, Medhin G, Vitale M, et al. Seroepidemiological study of ovine toxoplasmosis in East and West Shewa Zones of Oromia regional state, Central Ethiopia. BMC Vet Res. 2013;9:117.

40. Mason S, Quinnell JR, Smith JE. Detection of Toxoplasma gondii in lambs via PCR screening and serological follow -up. UK. Vet Parasitol. 2010;4:192-5.

41. Barakat AM, Abdelaziz MM, Fadaly M. Comparative diagnosis of toxoplasmosis in Egyptian small ruminants by indirect hemagglutination assay and ElISA. Global Veterinaria. 2009;3:9-14.

42. Zewdu E, Agonafir A, Tessema TS, Tilahun G, Medhin G, Vitale M, et al. Seroepidemiological study of caprine toxoplasmosis in East and West Shewa Zones, Oromia Regional State, Central Ethiopia. Res Vet Sci. 2013;94:43-8

43. Yibeltal MM. Seroprevalence study of toxoplasmosis in small ruminants and humans (HIV/AIDS patient) in selected district of South Wollo, Ethiopia, MSc Thesis. Debre-Zeit: Addis Ababa University, Faculty of Veterinary Medicine; 2008. p. 25-40.

44. Jittapalapong S, Sangvaranond A, Pinyopanuwat N, Chimnoi W, Khachaeram W, Koizumi S, Maruyama S. Seroprevalence of Toxoplasma gondii infection in domestic goats in Satun province, Thailand. Vet Parasitol. 2005:127:17-22.

45. Hove T, Lind P, Mukaratirwa S. Seroprevalence of Toxoplasma gondii infection in goats and sheep in Zimbabwe. Onderstepoort J Vet Res. 2005;72:267-72
46. Innes EA, Bartley PM, Buxton D, Katzer F. Ovine toxoplasmosis. Vet Parasitol. 2009;136:1884-7.

47. Jones JL, Moran KD, Wilson M, McQuillan G, Navin T, James B, McAuley JB. Toxoplasma gondii infection in the United States: Seroprevalence and risk Factors. Am J Epidemiol. 2001;154:357-65.

48. O'Donoghue PJ, Riley MJ, Clarke JF. Serological survey for Toxoplasma infections in sheep. Aust Vet J. 1987;64:40-5.

49. Van der Puije WNA, Bosompem KM, Canacoo EA, Wastling JM, Akanmori BD. The prevalence of anti-Toxoplasma Gondii antibodies In Ghanaian sheep and goats. Acta Trop. 2000;76:21-6.

50. Dubey JP, Lappin MR. Toxoplasmosis and Neosporosis. In: Greene CE, editor. Infectious Diseases of the Dog and Cat. Philadelphia: WB Saunders; 1998. p. 493-509.

\section{Submit your next manuscript to BioMed Central and we will help you at every step:}

- We accept pre-submission inquiries

- Our selector tool helps you to find the most relevant journal

- We provide round the clock customer support

- Convenient online submission

- Thorough peer review

- Inclusion in PubMed and all major indexing services

- Maximum visibility for your research

Submit your manuscript at www.biomedcentral.com/submit
C) Biomed Central 